\title{
Callus-mediated Somatic Embryogenesis and Plant Regeneration in Vanda tricolor Lindl. var. Pallida
}

\author{
Popy Hartatie Hardjo ${ }^{1, *}$, Wina Dian Savitri ${ }^{1}$, Ida Bagus Made Artadana ${ }^{1}$, \\ Sulistyo Emantoko Dwi Putra ${ }^{1}$, Elizabeth Pio Parac ${ }^{2}$ and Asad Jan ${ }^{3}$ \\ ${ }^{1}$ Faculty of Biotechnology, University of Surabaya, Jalan Raya Kalirungkut, Surabaya 60292, East Java, Indonesia; ${ }^{2}$ College of Agriculture \\ and Agri-Industries, Caraga State University, Amapayon, Butuan City, 8600 Philippines; ${ }^{3}$ Institute of Biotechnology and \\ Genetic Engineering, University of Agriculture, Peshawar, Pakistan
}

Received: May 20, 2021; Revised: June 18, 2021; Accepted: June22, 2021

\begin{abstract}
In this study, a protocol to induce indirect somatic embryogenesis from the basal leaf segments of Vanda tricolor Lindl. var. Pallida has been developed. The experiments consisted of two stages ، i.e. induction of SEs from calli and regeneration of plantlet from SEs. Embryogenic calli obtained from previous experiment $\left(0.05 \mathrm{mg} \mathrm{L}^{-1} \mathrm{NAA}+0.01 \mathrm{mg} \mathrm{L}^{-1} \mathrm{BAP}\right)$ were used to induce somatic embryos (SEs) on half-strength Murashige and Skoog (MS) medium supplemented with (0.05 $\mathrm{mg} \mathrm{L}^{-1}$ to $0.20 \mathrm{mg} \mathrm{L}^{-1}$ ) 6-benzylaminopurine (BAP) alone or in combination with $0.01 \mathrm{mg} \mathrm{L}^{-1} \alpha$-naphtalene acetic acid (NAA). Embryogenic calli, those cultured on $0.05 \mathrm{mg} \mathrm{L}^{-1}$ BAP and $0.01 \mathrm{mg} \mathrm{L}^{-1}$ NAA resulted in $90 \%$ induction of SE structures at $30 \mathrm{~d}$ of culture period. Histological observation exhibited development of pro-embryo to form completed embryo. The pattern of SEs development started from embryogenic callus to form pro-embryo, followed by globular phase at $10 \mathrm{~d}$ of culture. Globular embryo elongated to form suspensor at $20 \mathrm{~d}$ of incubation period, and completed embryo. Regeneration of SEs into complete plantlets was attained on the half-strength MS medium without addition of any plant growth regulator (PGR). Based on the results of the present study, it can be concluded that half-strength MS medium supplemented with NAA $0.01 \mathrm{mg} \mathrm{L}^{-1}$ and BAP $0.05 \mathrm{mg} \mathrm{L}^{-1}$ is the best medium for induction of SEs from embryogenic calli.
\end{abstract}

Keywords: Embryogenic calli, Histology, Half-strength Murashige-Skoog medium, Micropropagation, Orchid, Pro-embryo

\section{Introduction}

Vanda is a genus of orchids that consists of approximately 50 species. Vanda tricolor, just like its name, has fragrant flowers composed of three colors, i.e. white sepal, white with brown spot petal, and violet labellum. Vanda tricolor Lindl. in the slope of Mount Merapi located in Central Java, and Vanda tricolor Lindl. var. pallida in Amerta Jati Forest, Bali are local endemic species labelled endangered in Indonesia (Kurniawan et al., 2020; Semiarti, 2018). These species are generally used as the parental for crossing to produce hybrids that have economic value.

The propagation of orchids, in most cases, is done by seed germination by in vitro culture. Thus, the result is not homogeneous and the flowers are varied. To overcome this problem, the clonal multiplication by using in vitro technique can be performed. Besides, V. tricolor as well as $V$. testacea are monopodial orchids that are not easy to be propagated vegetatively in conventional method (Sebastinraj et al., 2014). It is necessary to develop a rapid and efficient micropropagation protocol in large quantities and in a short period of time. Micropropagation through callus has the potential for somaclonal variation, so it should be carried out in a shorter culture period as well as reducing costs (Melviana et al. 2021a).
Cardoso et al. (2020) stated that induction, proliferation and regeneration of protocorm-like bodies (PLBs) is one of the most advantageous methods for mass propagation of orchids. In vitro multiplication by direct or indirect embryogenesis through callus will result in somatic embryo(s). According to Naing et al. (2011) and Shen et al. (2018), embryogenesis in orchids, both direct and indirect, occurred through the development of protocormlike bodies (PLBs). Thidiazuron cytokinin $(<1 \mu \mathrm{M})$ significantly stimulated formation and regeneration of PLBs compared to other plant growth regulators (Kundu and Gantait, 2018). Lee et al. (2013) stated that in early stage of PLBs development, the cells had characteristics that cytologically similar to that of the zygotic embryos. Therefore, it was concluded that PLBs were actually somatic embryos (SEs) in orchids. As reported by Jainol and Gansau (2017), embryogenic callus developed into nodular structures and progressed further formed into aggregates of PLBs. Somatic embryogenesis was a process where cells developed resemble the zygotic embryos with bipolar structure (Shen et al., 2018). The use of somatic embryo derived from callus tissue was chosen in this research because the produced propagules were unlimited where each somatic embryo originated from a somatic cell, i.e. callus cell.

Orchids propagation using protocorm-like bodies had been studied by Soe et al. (2014). In addition to that,

\footnotetext{
*Corresponding author e-mail: poppy_hardjo@staff.ubaya.ac.id.
} 
somatic embryogenesis protocols from several orchids have been reported, for examples Phalaenopsis bellina (Rchb.f.) Christenson (Khoddamzadeh et al., 2011), Phalaenopsis amabilis (L.) - Blume Orchid (Mose et al., 2017, Mose et al., 2020), Tolumnia Louise Elmore 'Elsa' (Shen et al., 2018). Concentration and combination of plant growth regulators play an important role throughout in vitro proliferation of different orchids. Auxins, especially $\alpha$-naphtalene acetic acid (NAA) affect the process of regeneration in monopodial orchids, and act synergistically on the formation of PLBs (Jainol and Gansau, 2017). Hardjo and Savitri (2017) succeeded in callus induction from the basal part of $V$. tricolor var. pallida's leaf using half-strength MS medium (Melviana, et al, 2021b; Murashige and Skoog, 1962) with the addition of $0.05 \mathrm{mg} \mathrm{L}^{-1} \mathrm{NAA}$ in collaboration with 0.01 mg $\mathrm{L}^{-1}$ BAP. Callus induction method which has been done by Hardjo and Savitri (2017) will be used and developed to induce somatic embryos and then to regenerate them into plantlets. The effect of NAA and BAP was studied for induction and maturation of somatic embryos. This study intended to develop a protocol to indirectly produce somatic embryo (SE) via callus, initiated from leaf basal segment of $V$. tricolor var. Pallida.

\section{Materials and Method}

\subsection{Plant material}

In vitro grown plantlets of $V$. tricolor var. Pallida were provided by Handoyo Budi Orchid, in Malang City, East Java, Indonesia. Three-month old in vitro plantlets, measuring $3 \mathrm{~cm}$ had four leaves and long roots. Leaf basal segments were used as explant source for callus induction.

\subsection{2 Induction and regeneration of somatic embryo}

Basal segment of leaf was cultured on half-strength MS medium $+0.05 \mathrm{mg} \mathrm{L}^{-1} \mathrm{NAA}+0.01 \mathrm{mg} \mathrm{L}^{-1} \mathrm{BAP}$ (following Hardjo and Savitri, 2017). Subculturing was carried out after 4 wk (week)s intervals. The experiments consisted of two stages, i.e. induction of SEs from calli and regeneration of plantlet from SEs. Embryogenic calli (approx. $5 \mathrm{~mm}$ in diameter), formed after subculturing, were transferred to half-strength MS medium added with various levels of BAP $\left(0.05 \mathrm{mg} \mathrm{L}^{-1}\right.$ to $0.20 \mathrm{mg} \mathrm{L}^{-1}$ and $0.01 \mathrm{mg} \mathrm{L}^{-1} \mathrm{NAA}$ ) to induce SEs.

\subsection{Culture conditions}

The half-strength MS basal medium contained halfstrength macro- and micro-element of MS enriched with: myo-inositol (100 $\left.\mathrm{mg} \mathrm{L} \mathrm{L} \mathrm{L}^{-1}\right)$, niacin $\left(0.5 \quad \mathrm{mg} \mathrm{L} \mathrm{L}^{-1}\right)$, pyridoxine. $\mathrm{HCl}\left(0.5 \mathrm{mg} \mathrm{L}^{-1}\right)$, thiamine $\mathrm{HCl}\left(0.1 \mathrm{mg} \mathrm{L}^{-1}\right)$, glycine (2.0 $\mathrm{mg} \mathrm{L}^{-1}$ ), sucrose (10 $000 \mathrm{mg}$ ), and phytagel (2 $500 \mathrm{mg}$ ). Plant growth regulators as well as compulsory additives (according to the experimental objectives) were added to the media prior to autoclaving. The $\mathrm{pH}$ of the media was adjusted to 5.8 with $1 \mathrm{~N} \mathrm{KOH}$ or $\mathrm{HCl}$ prior to autoclaving for $20 \mathrm{~min}$ at $121{ }^{\circ} \mathrm{C}$. Explants were incubated under 16 :8-h photoperiod at $24{ }^{\circ} \mathrm{C}$ to $26{ }^{\circ} \mathrm{C}$. Subculturing was also executed every $4 \mathrm{wk}$.

\subsection{Histological observation of SE}

The tissue was fixed in formaldehyde-acetic acid ethanol (FAA) solution (5\% formaldehyde: $5 \%$ glacial acetic acid: $90 \%$ ethanol $70 \%$ ) for $24 \mathrm{~h}$, then continued with further processes (washing and gradual dehydration) until finally the tissue was covered in paraffin. The paraffin embedded tissue was cut at a thickness of $5 \mu \mathrm{m}$, and stained with hematoxylin-eosin. At the end, the specimen was then observed under the light microscope.

2.5. Complete plantlet regeneration and acclimatization

Regeneration of SE was performed on hormone-free MS medium and half strength MS + BAP $\left(0 \mathrm{mg} \mathrm{L}^{-1}\right.$ to $0.05 \mathrm{mg} \mathrm{L}^{-1}$ ). The observations were recorded weekly to trace different stages of protocorm development. For stereo microscopy and histological observations, about five PLBs at every developmental stage were randomly collected from culture tubes. Plantlets with four leaves and three roots were transplanted into a 2-inch pot containing sphagnum moss and were covered with a clear plastic lid in greenhouse. Plastic lids were removed after $15 \mathrm{~d}$. The moisture content of the pots was maintained by regular water spraying. Survival plantlets were recorded 2 mo after transplanting.

\subsection{Experimental design and statistical analysis}

The experiment was based on completely randomized design. Each experiment was composed of six treatments and 40 replications. Embryogenic callus induction from basal leaf explant was carried out as long as 4 wk. Embryogenic calli were transferred to various treatment media to promote somatic embryo formation. Observation parameters for SE induction were the initial time of SE formation, percentage of callus forming SE, and histological analysis of SE. For the observation of SE regeneration, the parameters were the initial time of emerging shoot, percentage of SE forming shoots, and percentage of SE forming plantlet. Data were analyzed with analysis of variance (ANOVA) and followed by Duncan's Multiple Range Test (DMRT) at $\alpha=0.05$ (Adinurani, 2016)

\section{Results and Discussions}

\subsection{Embryogenic callus induction and stages of $S E$}

Basal leaf of $V$. tricolor var pallida's explant formed callus on half-strength MS medium + NAA $0.05 \mathrm{mg} \mathrm{L}^{-1}+$ BAP $0.01 \mathrm{mg} \mathrm{L}^{-1}$ (Figure 1A). Naing et al. (2011) reported the same thing that high auxin and cytokinin ratio has synergistic effect to induce callus on Coelogyne cristata Lindl. leaf explant. Figure 1B shows that after first subculture, callus structure shaped nodule and compact, with isodiametric size and shiny green in color. According to Jainol and Gansau (2017), these characteristics are typical in embryogenic callus and will be subsequently developed into embryo. Figure $1 \mathrm{C}$ represents callus that develop into SE, while the nodule size is bigger than others and color is dark green. 

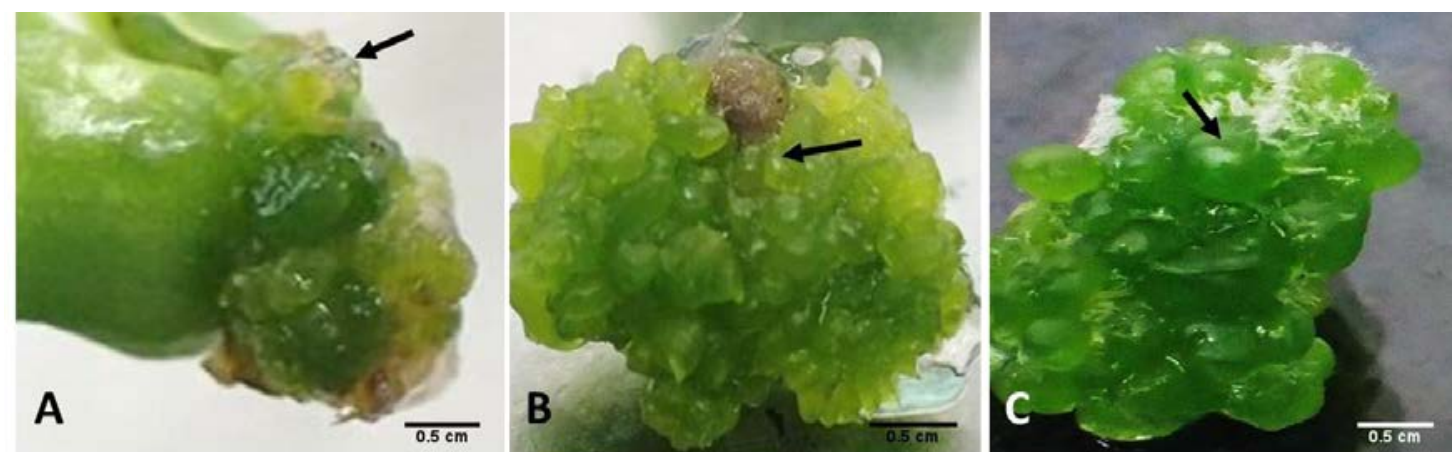

Figure 1. Callus formation on V. tricolor var. pallida basal leaf segment A. 8 wk of culture $\left(\frac{1}{2} 2 \mathrm{MS}\right.$ medium + NAA $0.05 \mathrm{mg} \mathrm{L}^{-1}+\mathrm{BAP}$ $0.01 \mathrm{mg} \mathrm{L}^{-1}$ ); B. Embryogenic callus; C. SEs at globular phase

Treatment of $0.05 \mathrm{mg} \mathrm{L}^{-1} \mathrm{BAP}$ and $0.01 \mathrm{mg} \mathrm{L}^{-1} \mathrm{NAA}$, all at once, was able to induce SE formation (90\%) in faster time rather than single BAP treatment $\left(0.05 \mathrm{mg} \mathrm{L}^{-1}\right.$ to $0.2 \mathrm{mg} \mathrm{L}^{-1}$ ) as shown in the Table 1 . Combination of NAA with cytokinin like BAP on various orchid species can increase the formation of PLBs such as Tolumnia cv. Snow Fairy (0.5 mg L ${ }^{-1}$ NAA with $\left.4 \mathrm{mg} \mathrm{L}^{-1} \mathrm{BA}\right)$ (Chookoh et al., 2019) while on leaf explant of Phalaenopsis 'Join Angle $\times$ Sogo Musadian' $2 \mathrm{mg} \mathrm{L} \mathrm{L}^{-1}$ 2,4-D was applied in combination with $1 \mathrm{mg} \mathrm{L}^{-1} \mathrm{TDZ}$ but number of PLBs was less than the combination treatment of $0.5 \mathrm{mg} \mathrm{L}^{-1} \mathrm{NAA}, 5 \mathrm{mg} \mathrm{L}^{-1} \mathrm{BAP}$, and $0.5 \mathrm{mg} \mathrm{L}^{-1}$ IAA that used root explant (Meilasari and Iriawati 2016). Furthermore, Mose et al. (2020), also reported combination of $3 \mathrm{mg} \mathrm{L}$ TDZ with $1 \mathrm{mg} \mathrm{L}$ NAA effectively induced Phalaenopsis amabilis L. (Blume) SEs formation from stem explants. Basal segment explants of Dendrobium (Sw) Sonia 'Earsakul' cultured on $1 / 2$ MS medium supplemented with $1 \mathrm{mg} \mathrm{L^{-1 }}$ TDZ alone could be stimulated to form PLBs (Juntada et al., 2015). In numerous orchids, SE induction has been completed with cytokinin alone or as a group with auxin at low concentration. The effect of various concentration is variable, depending on the type of explant and species. The decrease of auxin concentration results in inhibition of cell division and cells are encouraged to develop into embryos.

Table 1. Percentage of callus forming SE and time duration of SE maturation in $V$. tricolor var. pallida at various concentration and combination of BAP and NAA.

\begin{tabular}{lll}
\hline $\begin{array}{l}\text { PGR treatment } \\
\left(\mathrm{mg} \mathrm{L}^{-1}\right)\end{array}$ & $\begin{array}{l}\text { Time duration } \\
\text { formed SEs (d) }\end{array}$ & $\begin{array}{l}\text { Percentage of callus } \\
\text { formed SEs after 30 d } \\
\text { cultured (\%) }\end{array}$ \\
\hline BAP 0.2 + NAA 0.01 & $65.7 \pm 0.65^{\mathrm{c}}$ & $60.2 \pm 8.92^{\mathrm{bc}}$ \\
BAP 0.1 + NAA 0.01 & $45.3 \pm 0.52^{\mathrm{d}}$ & $70.2 \pm 5.45^{\mathrm{b}}$ \\
BAP 0.05 + NAA 0.01 & $30.8 \pm 0.84^{\mathrm{e}}$ & $90.1 \pm 4.72^{\mathrm{a}}$ \\
BAP 0.2 & $112.3 \pm 0.75^{\mathrm{b}}$ & $60.1 \pm 7.65^{\mathrm{bc}}$ \\
BAP 0.1 & $120.5 \pm 0.64^{\mathrm{b}}$ & $55.4 \pm 9.83^{\mathrm{c}}$ \\
BAP 0.05 & $130.2 \pm 0.54^{\mathrm{a}}$ & $50.3 \pm 8.15^{\mathrm{c}}$
\end{tabular}

Note.: numbers followed by different letter in a column means that they are significantly different, tested with DMRT at $\alpha=0.05$. There were 40 explants used for every treatment.

According to histological observation of longitudinal section of $V$. tricolor var. pallida's SE, it was noticeable that there were embryogenic cells in the form of proembryo which consisted of three cells (Figure 2A), and then developed into globular shape (Figure 2B), and differentiation occurred where cells in apical area were small while they were huge in basal area (Figure 2C).
Furthermore, globular structure started to elongate at basal area, forming a suspensor-like structure and at apical area it formed a curvature, consequently there were two bulges (Figure 2D). At next development, the two bulges transformed into two leaves primordial, while the curvature developed into shoot apical meristem (Figure $2 \mathrm{E})$. Figure $2 \mathrm{~F}$, exhibits that there was cell differentiation at the center of the specimen to form vascular tissue which will connect shoot apical meristem and root apical meristem. Embryogenic calli were able to form embryos because medium contained BAP cytokinin combined with low content of NAA $\left(0.01 \mathrm{mg} \mathrm{L}^{-1}\right)$.
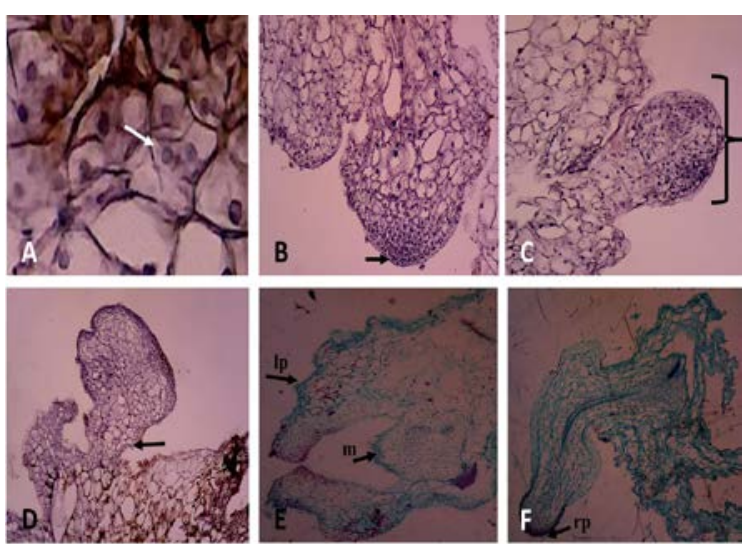

Figure 2. Histology of SE from callus of $V$. tricolor var. pallida.

A. Proembryo (three cells); B. SE on $1 / 2$ MS medium

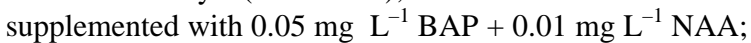
C. Globular stage of SE; D. Basal of SE with suspensorlike structure; E. Shoot apical meristem after $30 \mathrm{~d}$ on hormone-free $1 / 2$ MS medium; F. Differentiation of the procambium at SE. $(\mathrm{m}=$ meristem; $\mathrm{lp}=$ leaf primordia; $\mathrm{rp}=$ root primordia)

\subsection{Regeneration of $S E$ to form plantlets}

First and foremost, SE (Figure 3A) regenerated to form shoot (Figure $3 \mathrm{~B}$ ) occurred in a faster time on hormonefree half strength MS. Yet, it was not significantly different with half-strength MS supplemented with BAP at low concentration to $0.02 \mathrm{mg} \mathrm{L}^{-1}$ (Table 2). In line with that, there was a same report on protocorms in Phalaenopsis (Winarto et al., 2016), regeneration of Phalaenopsis bellina (Rchb.f.) PLBs (Chew et al., 2018) and SE in Tolumnia Louise Elmore 'Elsa' (Shen et al., 2018) which regenerated into plantlets after being transferred to hormone-free half-strength MS medium. The addition of BAP in higher concentration from $0.02 \mathrm{mg} \mathrm{L}^{-1}$ evidently had an effect to slow down germination of SE to form plantlets and caused germination time to be delayed. 
High concentration of BAP actually inhibit SE germination. Morphological observation (Figure 3C) showed that the roots emerge after the first and second leaf develop. In a period of $30 \mathrm{~d}$ of culture (Table 2) all of SEs (100\%) form whole plantlets, while on MS medium and half-strength $\mathrm{MS}+\mathrm{BAP} \geq 0.03 \mathrm{mg} \mathrm{L}^{-1}$ only $80 \%$ SEs form plantlets. Low concentration cytokinin has beneficial effect on SE germination of $V$. tricolor var. pallida. Naing et al. (2011) stated that BAP effectively promote regeneration on Coelogyne cristata (Lindl.)'s PLBs to form shoots, and it was similar to the result reported by Zhao et al. (2013) using Dendrobium wangliangii (G.W.Hu, C.L.Long \& X.H.Jin). Generally, cytokinins have the effect of encouraging cell division and regeneration to form shoots, and the optimum concentration is specific for each species. Cytokinin BA are also commonly used for in vitro shoot multiplication of various species such as for example Ammi visnaga (L.) Lam. (Al-Saleh et al., 2019).
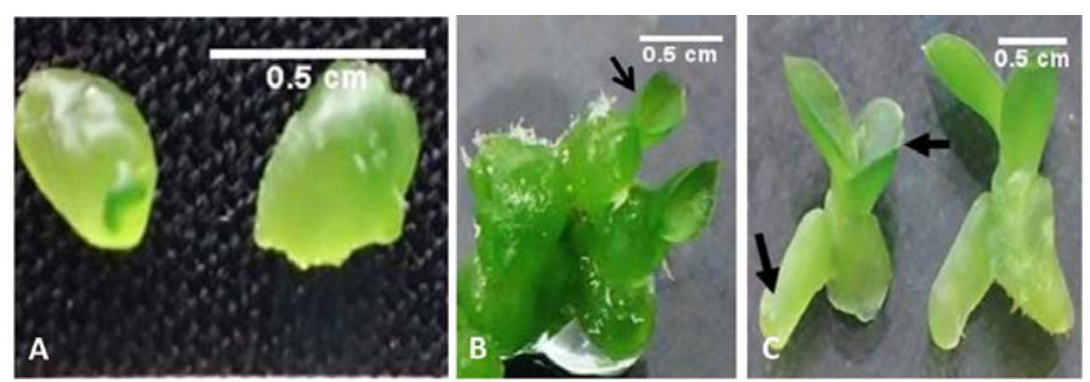

Table 2. Regeneration of SEs of $V$. tricolor var. Pallida forming plantlets on half-strength MS and MS supplemented with PGRs after $30 \mathrm{~d}$ of culture period

\begin{tabular}{llll}
\hline $\begin{array}{l}\text { Medium and PGR } \\
\left(\mathrm{mg} \mathrm{L}^{-1}\right)\end{array}$ & $\begin{array}{l}\text { SE forming } \\
\text { shoot (d) }\end{array}$ & $\begin{array}{l}\text { Percentage of } \\
\text { SE forming } \\
\text { shoot }(\%)\end{array}$ & $\begin{array}{l}\text { Percentage of SE } \\
\text { forming plantlet } \\
(\%)\end{array}$ \\
\hline $\mathrm{MS}$ & $25.5 \pm 2.27^{\mathrm{a}}$ & 80 & 85 \\
$1 / 2 \mathrm{MS}$ & $17.8 \pm 3.45^{\mathrm{c}}$ & 100 & 100 \\
$1 / 2 \mathrm{MS}+$ BAP 0.01 & $15.2 \pm 2.68^{\mathrm{c}}$ & 100 & 100 \\
$1 / 2 \mathrm{MS}+$ BAP 0.02 & $16.4 \pm 2.85^{\mathrm{c}}$ & 100 & 100 \\
$1 / 2 \mathrm{MS}+$ BAP 0.03 & $20.8 \pm 2.85^{\mathrm{b}}$ & 90 & 80 \\
$1 / 2 \mathrm{MS}+$ BAP 0.05 & $22.4 \pm 2.85^{\mathrm{b}}$ & 80 & 80 \\
\hline
\end{tabular}

Note.: numbers followed by different letter in a column means that they are significantly different, tested with DMRT at $\alpha=0.05$. There were 40 explants used for every treatment.

The percentage of plantlets (Figure. 3D) that were well acclimatized in the glasshouse with survival rate $95 \%$. These plantlets were grown in sphagnum moss medium and exhibited normal developmental (Figure 3E). Sphagnum moss was used to maintain the moisture.

Figure 3. Mature SE of Vanda tricolor Lindl. var. pallida transformed into plantlet on hormone-free half-strength MS medium. A. Somatic embryo (SE); B. SE with shoot; C. SE with shoot and root; D. Plantlet; E. Acclimatized plantlets (2 mo old after planting)

\section{Conclusion}

Embryogenic calli formed SEs on $1 / 2$ MS medium + NAA $0.01 \mathrm{mg} \mathrm{L}^{-1}+$ BAP $0.05 \mathrm{mg} \mathrm{L}^{-1}$ at $30 \mathrm{~d}$ of culture period. The development of embryo started with the formation of proembryo structure from embryogenic callus and then developed into globular structure with suspensor. Somatic embryo could germinate to form shoots firstly and subsequently form root on hormone-free half-strength MS medium after $30 \mathrm{~d}$ of culture period. Plantlets regenerated through somatic embryogenesis would be a new procedure of clonal propagation in $V$. tricolor.

The success in somatic embryo formation from callus followed by the establishment of Vanda tricolor Lindl. var. Pallida plantlets opened the chance to develop orchid synthetic seed and advanced plant breeding.

\section{Acknowledgement}

This research was funded by Campus Intellectual Product Business Development Program Grant [Hibah Program Pengembangan Usaha Produk Intelektual Kampus (PPUPIK)] Kemendikbud-Ristek 2021 with contract no. 004/SPP-PPM/LPPM-02/DRPM/FTB/IV/ 2021 (on behalf of Dr.rer.nat. Sulistyo Emantoko Dwi Putra). All experiments were conducted in Faculty of Biotechnology University of Surabaya. The authors would like to thank to our laboratory assistants and students for their intensive helped to support this research.

\section{References}

Adinurani PG. 2016. Agro Experimental Data Design and Analysis. Plantaxia, Yogyakarta, Indonesia

Al-Saleh MM, Shibli RA, Al-Qadiri HM, Tahtamouni RW, Darwish MM and Al-Qudah TS. 2019. Investigating the antimicrobial potential of in- vitro grown microshoots and callus cultures of Ammi visnaga (L.) Lam. Jordan J of Biol Sci. 12(1):43-48.

Cardoso JC, Zanello CA and Chen JT. 2020. An overview of orchid protocorm-like bodies: Mass propagation, biotechnology, molecular aspects, and breeding. Int. J. of Mol Sci., 21 (985): 1-32.

Chew YC, Halim MHA, Wan Abdullah MAN, Abdullah JO and Lai KS. 2018. Highly efficient proliferation and regeneration of protocorm like-bodies (PLBs) of the threatened orchid Phalaenopsis bellina. Sains Malays, 47(6):1093-1099.

Chookoh N, Chiu YT and Chang C. 2019. Micropropagation of Tolumnia orchids through induction of protocorm-like bodies from leaf segments. Hortscience 54(7):1230-1236.

Hardjo PH and Savitri WD. 2017. Somatic embryo from basal leaf segments of Vanda tricolor Lindl. var. pallida. KnE Life Sci 3(5):173-179.

Jainol JE and Gansau JA. 2017. Embryogenic callus induction from leaf tip explants and protocorm-like body formation and shoot proliferation of dimorphorchis lowii: Borneon endemic orchid. Agrivita J of Agricultural Science. 39(1): 1-10. 
Juntada K, Taboonmee S, Meetum P, Poomjae S and Chiangmai PN. 2015. Somatic embryogenesis induction from protocorm likebodies and leaf segments of Dendrobium Sonia 'Earsakul'. Silpakorn U. Science \& Tech. J. 9(2):9-19.

Khoddamzadeh AA, Sinniah UR, Kadir MA, Kadzimin SB, Mahmood M and Sreeramanan S. 2011. In vitro induction and proliferation of protocorm-like bodies (PLBs) from leaf segments of Phalaenopsis bellina (Rchb.f.) Christenson. Plant Growth Regul. 65:381-387.

Kundu S and Gantait S. 2018. Thidiazuron-induced protocormlike bodies in orchid: progress and prospects. In: N Ahmad, M Faisal (eds.), Thidiazuron: From Urea Derivative to Plant Growth Regulator, Volume 1, Springer Nature, Singapore, pp. 273-287.

Kurniawan FY, Putri F, Suyoko A, Masyhuri H, Sulistianingrum MP and Semiarti E. 2020. The diversity of wild orchids in the southern slope of Mount Merapi, Yogyakarta, Indonesia eight years after the 2010 eruption. Biodiversitas 21(9):4457-4465.

Lee YI, Hsu ST, and Yeung EC. 2013. Orchid protocorm-like bodies are somatic embryos. Am. J. Bot., 100(11):2121-2131.

Meilasari D and Iriawati. 2016. Regeneration of planlets through PLB (protocorm-like body) formation in Phalaenopsis 'Join Angle X Sogo Musadian’. J. Math. Fundam. Sci. 48(3):204-212.

Melviana AC, Esyanti RR, Mel M and Setyobudi RH. 2021a. Biomass enhancement of Stevia rebaudiana Bertoni shoot culture in temporary immersion system (TIS) RITA ${ }^{\circledR}$ bioreactor optimized in two different immersion periods. E3S Web Conf. 226(00007): 1-9.

Melviana AC, Esyanti RR, Setyobudi RH, Mel M, Adinurani PG and Burlakovs J. 2021b. Gene expression related to steviol glycoside synthesis produced in Stevia rebaudiana (Bert.) shoot culture induced with high Far-Red LED light in TIS RITA ${ }^{\circledR}$ bioreactor system. Sarhad J. Agric, 37(1): 1-8

Mose W, Daryono BS, Indrianto A, Purwantoro A and Semiarti E. 2020. Direct somatic embryogenesis and regeneration of an Indonesian orchid Phalaenopsis amabilis (L.) Blume under a variety of plant growth regulators, light regime, and organic substances. Jordan J of Biol Sci. 13(4):509-518.
Mose W, Indrianto A, Purwantoro A and Semiarti E. 2017. The influence of thidiazuron on direct somatic embryo formation from various types of explant in Phalaenopsis amabilis (L.) Blume orchid. Hayati 24(4):201-205.

Murashige T and Skoog F. 1962. A revised medium for rapid growth and bio assays with tobacco tissue cultures. Physiol. Plant. 15:473-497

Naing AH, Chung JD, and Lim KB. 2011. Plant regeneration through indirect somatic embryogenesis in Coelogyne cristata Orchid. Am. J. Plant Sci., 2(2):262-267.

Parthibhan S, Rao MV, DaSilva JAT and Kumar TS. 2018. Somatic embryogenesis from stem thin cell layers of Dendrobium aqueum. Biol. Plant., 62(3):439-450.

Sebastinraj J, Britto SJ, Kumar DV, Robinson JP, and Thangavel P. 2014. Rapid propagation of Vanda testacea (Lindl.) Rchb.F. -A highly medicinal value epiphytic orchid of India. World $J$ of Agricultural Sciences 10(5):223-230.

Semiarti E. 2018. Orchid biotechnology for Indonesian orchids conservation and industry. AIP Conf. Proc. 2002(020022):1-5.

Shen HJ, Chen JT, Chung HH, and Chang WC. 2018. Plant regeneration via direct somatic embryogenesis from leaf explants of Tolumnia Louise Elmore 'Elsa'. Bot Stud 59(4):1-7.

Soe KW, Myint KT, Naing AH, and Kim CK 2014. Optimization of efficient protocorm-like body (PLB) formation of Phalaenopsis and Dendrobium hybrids. Curr. Res. Agric. Life Sci. 32(4):179183.

Winarto B, Atmini KD, Badriah DS and Wegadara M. 2016. In vitro embryogenesis derived from shoot tips in mass propagation of two selected-clone of Phalaenopsis. Not Sci Biol 8(3):317-325.

Zhao D, Hu G, Chen Z, Shi Y, Zheng L, Tang A and Long C. 2013. Micropropagation and in vitro flowering of Dendrobium wangliangii: A critically endangered medicinal orchid. $J$. Med. Plant Res., 7(28):2098-2110. 